GEOGRAFICKÝ ČASOPIS / GEOGRAPHICAL JOURNAL 70 (2018) 2, 161-177

https://doi.org/10.31577/geogrcas.2018.70.2.09

\title{
GEOGRAFICKÉ, ENVIRONMENTÁLNÍ A SOCIOEKONOMICKÉ DETERMINANTY CESTOVNÍHO RUCHU V MALÝCH OSTROVNÍCH ROZVOJOVÝCH STÁTECH (SIDS)
}

\author{
Zdeněk Opršal, Jaromír Harmáček* \\ *Univerzita Palackého v Olomouci, Př́rodovědecká fakulta, Katedra rozvojových a environmentálních studií, \\ 17. listopadu 12, 77146 Olomouc, Česká republika, zdenek.oprsal@upol.cz, jaromir.harmacek@upol.cz
}

\begin{abstract}
Geographic, environmental and socio-economic determinants of tourism in Small Island Developing States (SIDS)

Small Island Developing States (SIDS) represent a heterogeneous group of countries with specific development challenges. One of the common characteristics is a significant tourist potential which is not sufficiently exploited in many SIDS. The paper focuses on the analysis of factors that can influence the number of foreign tourists arriving in SIDS. The statistical significance of potentially relevant factors is examined by regression analysis applied to panel data over $2005-2016$. The results indicate that the key determinants of tourism demand are destination accessibility, climate (pattern of the weather) and the level of economic development of destinations. Hygienic conditions and tourism infrastructure development are also important factors for tourism inflows. On the contrary, the level of political stability and absence of violence/terrorism play a less statistically significant role in international tourist arrivals while the level of prices and the rate of intentional homicide do not show any statistical significance. The results also suggest that SIDS should improve transport and tourism infrastructure and that they should increase the hygienic standards to attract more international tourists. However, due to the inherent environmental fragility and cultural uniqueness of many small islands, the SIDS must pay special attention to sustainable tourism development at the same time.
\end{abstract}

Key words: tourism, international tourist arrivals, destination accessibility, Small Island Developing States (SIDS)

\section{ÚVOD}

Cestovní ruch se v posledních dekádách stal významným motorem ekonomického růstu. V roce 2016 se turismus podílel podle Světové rady cestování a cestovního ruchu (World Travel and Tourism Council - WTTC) na tvorbě celosvětového HDP 10,2 procenty a celosvětově vytvářel jednu desetinu pracovních míst (WTTC 2017). Prưměrný roční růst odvětví cestovního ruchu již několik let překonává celkový růst světové ekonomiky vyjádřený v HDP (WTTC 2017). Počet mezinárodních turistických př́jezdů dosáhl v roce 2016 rekordní hodnoty 1,2 miliardy, přičemž Světová organizace turistického ruchu (World Tourism Organisation UNWTO) očekává zvýšení až na 1,8 miliardy př́ijezdů v roce 2030 (UNWTO 2017). Potenciál cestovního ruchu pro rozvinuté, ale i rozvojové ekonomiky potvrzují studie vlivných mezinárodních organizací (UNWTO 2017, WEF 2017 a WTTC 2017). Cestovní ruch je součástí nové mezinárodní rozvojové agendy 2030 Agenda for Sustainable Development, která zahrnuje cestovní ruch do tř́ ze sedmnácti cílů udržitelného rozvoje (Sustainable Development Goals - SDGs); 
(UNWTO 2017). Valné shromáždění OSN vyhlásilo rok 2017 za „Mezinárodní rok udržitelného turismu pro rozvoj" (International Year of Sustainable Tourism for Development), čímž upozornilo na přínosy, ale i rizika turistického průmyslu pro udržitelný rozvoj (UN 2015).

Přínosy i rizika turistického odvětví pro rozvojové regiony jsou v důsledku dynamického růstu tohoto sektoru předmětem pozornosti řady autorů (např. Chock et al. 2007, Spenceley a Meyer 2012 a Chou 2013). Překvapivě málo pozornosti je však věnováno specifické skupině zemí označované jako „malé ostrovní rozvojové státy“ (Small Island Developing States - SIDS). Přestože z důvodu odlehlosti je řada malých ostrovních států v konkurenční nevýhodě oproti lépe dostupným turistickým destinacím, pro mnohé z nich představuje turismus jednu z mála př́ležitostí pro ekonomický rozvoj (UNWTO 2014). Zároveň však, kvůli jejich malé rozloze a přítomnosti křehkých ekosystémů, vyvolává nárůst turistického ruchu obavy o jeho dopady na místní ekosystémy a kulturní soudržnost obyvatelstva malých ostrovních rozvojových států (Scheyvens a Momsen 2008). V tomto duchu se vyjádřil také generální tajemník Světové organizace cestovního ruchu Taleb Rifai: „Cestovní ruch mưže hrát klíčovou roli při podpoře rozvojové agendy SIDS, jelikož cestovní ruch je hlavním hybatelem hospodářství mnoha malých ostrovních rozvojových států, avšak vzhledem k jejich zranitelnosti zůstávají SIDS zvláštní výzvou pro rozvoj udržitelného cestovního ruchu“(UNWTO 2014, p. 2).

Tento článek se zaměřuje především na ekonomickou stránku cestovního ruchu v rámci malých ostrovních rozvojových států. Cílem článku je odpovědět na otázku, které determinanty cestovního ruchu pro malé ostrovní rozvojové státy lze považovat za klíčové. Ćlánek se pokouší statisticky vyhodnotit význam vybraných geografických, environmentálních, ekonomických, sociálních a politicko-institucionálních faktorů, které mohou mít vliv na počet mezinárodních turistických př́ijezdů do malých ostrovních rozvojových států. Potenciálně významné faktory jsou identifikovány na základě rešerše dostupné literatury (nap̌r. Cho 2010, Gay 2012, Prideaux a McNamara 2012, Armstrong a Read 2014, Sharpley 2014 a Toader et al. 2014), podrobněji jsou diskutovány v části článku nazvaného ,determinanty cestovního ruchu v malých ostrovních rozvojových státech“. Pomocí regresních analýz jsou následně analyzovány proměnné, které lze označit za geograficko-environmentální (např. odlehlost ostrovní destinace, její rozloha či počet deštivých dnů), faktory ekonomické povahy (hrubý domácí produkt na osobu, rozvinutost turistické infrastruktury či cenová hladina v destinaci) a sociální a politické faktory (politická stabilita a absence násilí či terorismu, bezpečnostní situace v zemi či hygienické podmínky).

\section{VYMEZENÍ A CHARAKTERISTIKA MALÝCH OSTROVNÍCH ROZVOJOVÝCH STÁTÜ}

Skupina malých ostrovních rozvojových států (Small Island Developing States - SIDS) byla poprvé vymezena v roce 1992 na Konferenci OSN o životním prostředí a rozvoji (známé také jako Summit Země) v brazilském Rio de Janeiro (UNOHRLLS 2011). Uznání SIDS bylo potvrzeno v rámci Kapitoly 17 G strategického dokumentu Agenda 21, jednoho z klíčových výstupů konference (UN-OHRLLS 2011). V roce 1994 se na Barbadosu uskutečnila první mezinárodní konference (United Nations Global Conference on the Sustainable Development of SIDS) zaměřená na malé ostrovní rozvojové státy. Z konference vzešel Barbadoský akční 
program (Barbados Programme of Action - BPOA), který mimo jiné označil cestovní ruch jako významnou rozvojovou př́ležitost (UN 2014). Institucionalizace SIDS byla dále podpořena vznikem Úřadu vysokého zástupce OSN pro nejméně rozvinuté země, vnitrozemské rozvojové země a malé ostrovní rozvojové státy (UN Office of the High Representative for the Least Developed Countries, Landlocked Developing Countries and Small Islands Developing States - UN-OHRLLS) v roce 2001 (UNWTO 2017). Tento úřad založený z popudu Valného shromáždění OSN následně vytvořil oficiální seznam SIDS, který má v současné době 58 členů, z nichž je 38 mezinárodně uznaných nezávislých států a 20 závislých území (viz tab. 1). Nezávislé SIDS se sdružují v Alianci malých ostrovních států (Alliance of Small Island States - AOSIS), do které náleží 37 států (Bahrajn není součástí skupiny) a 5 závislých území se statusem pozorovatelů. Vzhledem k separatistickým tendencím některých ostrovních entit, např́klad Bougainville v Tichomoří (Baar 2017), není vyloučeno rozšíření seznamu SIDS - v minulosti nastal podobný príipad u Východního Timoru, který je členem skupiny SIDS. Posláním aliance AOSIS je vystupovat ve prospěch svých členských států na půdě OSN. AOSIS nemá formalizovanou organizační strukturu a funguje na základě konzultací a konsensu na plenárních zasedáních na úrovni ambasád jednotlivých malých ostrovních států v New Yorku (AOSIS 2015). Vedle pojmu SIDS se lze ve starší literatuře (viz. napřr. Weaver 1998) setkat také s termínem SISODs, tj. Small Island States or Dependencies (malé ostrovní státy nebo závislá území). Weaver (1998, p. 293) definuje SISODs jako ostrovy mající méně než 3 miliony obyvatel a rozlohu pevniny méně než 28 tisíc $\mathrm{km}^{2}$. Přesto UNWTO i UN-OHRLLS používají ve svých oficiálních materiálech termín SIDS, se kterým pracujeme i v našem článku.

Malé ostrovní rozvojové státy se nacházejí ve třech geografických oblastech. Nejvyšší počet (29 SIDS) je v Karibiku, následuje oblast Tichého oceánu (20 SIDS) a nejmenší počet (9 SIDS) se nalézá v široce vymezené oblasti Atlantického oceánu, Indického oceánu, Středozemního moře a Jihočínského moře (Atlantic ocean, Indian ocean, Mediterranean and South China Sea - AIMS). Tyto tři geografické subkategorie SIDS jsou definovány ze strany mezinárodních organizací (viz UN-OHRLLS 2011, UN-OHRLLS 2017, UNWTO 2014). Z tab. 1 je patrné, že oficiální seznam malých ostrovních rozvojových států zveřejněný UN-OHRLLS (UN-OHRLLS 2017) má některá specifika, zejména pokud se zaměř́me na samotný název skupiny. Zaprvé se jedná o poměrně heterogenní skupinu, která zahrnuje skutečně malé ostrovní státy (např́íklad karibské Dominika, Sv. Lucie nebo tichomořské Nauru či Palau), zastoupeny jsou však také výrazně rozlehlejší a lidnatější - Kuba či Papua-Nová Guinea. Zadruhé se nejedná pouze o ostrovy, ale v několika př́ípadech také o prímořské země (Belize, Guyana, Surinam a Guinea-Bissau). Zatřetí, přestože jde ve velké většině o rozvojové ekonomiky, přičemž devět SIDS patří do skupiny Nejméně rozvinutých zemí (LDCs), jsou členy SIDS dle klasifikace Světové banky (více k tématu viz např. Dušková et al. 2011 či Harmáček 2013) také ekonomiky s vysokým př́ijmem (jak státy, tak závislá území, např. Singapur, Bahrajn či Francouzská Polynésie). Pro Malé ostrovní rozvojové státy, které spadají do kategorie rozvojových zemí, je charakteristický vysoký podíl Oficiální rozvojové pomoci na jejich HDP (Opršal 2014). Konečně začtvrté - z celkového počtu 58 zemí je 38 členskými státy OSN, zbývajících 20 členů jsou závislá území, která nejsou samostatnými státy. 
Tab. 1. Seznam malých ostrovních rozvojových států

\begin{tabular}{|c|c|c|}
\hline Karibská oblast & Oblast Tichého oceánu & $\begin{array}{l}\text { Oblast Atlantického oceánu, } \\
\text { Indického oceánu, Středozemního } \\
\text { moře a Jihočínského moře }\end{array}$ \\
\hline $\begin{array}{l}\text { Americké panenské ostrovy }^{2} \\
\text { Anguilla }^{2} \\
\text { Antigua a Barbuda }^{1,4} \\
\text { Aruba }^{2,4} \\
\text { Bahamy }^{1,4} \\
\text { Barbados }^{1,4} \\
\text { Belize }^{1} \\
\text { Bermudy }^{2,4} \\
\text { Britské panenské ostrovy }^{2,4} \\
\text { Curaçao } \\
\text { Dominika }^{2,4} \\
\text { Dominikánská republika }^{1} \\
\text { Grenada }^{1} \\
\text { Guadeloupe }^{2} \\
\text { Guyana }^{1} \\
\text { Haiti }^{1,3} \\
\text { Jamajka }^{1} \\
\text { Kajmanské ostrovy }^{2,4} \\
\text { Kuba }^{1} \\
\text { Martinik }^{2} \\
\text { Montserrat }^{2} \\
\text { Portoriko } \\
\text { Surinam } \\
\text { Sv. Kitts a Nevis } \\
\text { Sv. Lucie } \\
\text { Svatý Martin } \\
\text { Sv. Vincent a Grenadiny } \\
\text { Trinidad a Tobago }^{1,4} \\
\text { Turks a Caicos } \\
2,4\end{array}$ & $\begin{array}{l}\text { Americká Samoa }^{2} \\
\text { Cookovy ostrovy }^{2} \\
\text { Fidži }^{1} \\
\text { Francouzská Polynésie }^{2,4} \\
\text { Guam }^{2,4} \\
\text { Kiribati }^{1,3} \\
\text { Marshallovy ostrovy }^{1} \\
\text { Mikronésie (Federativní státy) }^{1} \\
\text { Nauru }^{1} \\
\text { Niue }^{2} \\
\text { Nová Kaledonie }^{2,4} \\
\text { Palau } \\
\text { Papua Nová Guinea }^{1,4} \\
\text { Samoa }^{1} \\
\text { Severní Marianyy } \\
\text { Šalamounovy ostrovy }^{2,3} \\
\text { Tonga }^{1} \\
\text { Tuvalu } \\
\text { Vanuatu }^{1,3} \\
\text { Východní Timor }\end{array}$ & $\begin{array}{l}\text { Bahrajn }^{1,4} \\
\text { Guinea-Bissau }^{1,3} \\
\text { Kapverdy }^{1} \\
\text { Komory }^{1,3} \\
\text { Maledivy }^{1} \\
\text { Mauricius }^{1} \\
\text { Seychely }^{1,4} \\
\text { Singapur } \\
\text { Svatý Tomáš a Princův ostrov } \\
\text { 1,3 }\end{array}$ \\
\hline
\end{tabular}

Poznámky: ${ }^{1}$ členské státy OSN, ${ }^{2}$ závislá území, ${ }^{3}$ nejméně rozvinuté země, ${ }^{4}$ ekonomiky s vysokými přijmy.

Zdroj: autoři na základě UN-OHRLLS (2017).

Přes určitou nesourodost skupiny sdílejí členové SIDS tři klíčové charakteristiky, které je činí specifickými z hlediska rozvoje (UNWTO 2017). První je malá velikost, což má za následek zvýšený tlak na př́rodní zdroje a omezenou diverzitu národního hospodářství. Druhou výzvu představuje odlehlost a izolovanost, které limitují rozvoj obchodu, avšak zároveň pomáhají uchovat unikátní př́rodní a kulturní různorodost. Třetí charakteristikou je přímořské prostředí, které představuje př́ležitost $\mathrm{z}$ hlediska turistického ruchu, ale zároveň je činí zranitelnými vůči extrémním klimatickým jevům a změnám klimatu. Přestože se malé ostrovní rozvojové státy liší co do úrovně ekonomického a sociálního rozvoje, je pro ně typická vysoká míra závislosti na turistickém ruchu z hlediska exportu a podílu na hrubém domácím produktu.

Průměrný přímý podíl cestovního ruchu na HDP je ve všech třech oblastech poměrně podobný, pro SIDS v karibské oblasti činil v roce 2016 tento podíl $10,5 \%$, pro AIMS 14,5 \% a pro SIDS v tichomořské oblasti byl nejnižší - 9,2 \% (WTTC 2018). Jedná se o část HDP, která je generována př́mo sektorem cestovního ruchu, tedy odvětvími, jež přichází do př́mého kontaktu s turisty, včetně hotelů, cestovních agentur, leteckých společností a pod. Obdobně vyrovnaný byl v roce 2016 průměrný přímý podíl cestovního ruchu na zaměstnanosti. V tomto případě se 
jedná o část pracovních míst vytvořených přímo $\mathrm{v}$ sektoru cestovního ruchu, tedy v odvětvích, která přímo pracují s turisty, včetně hotelů, cestovních agentur, leteckých společností apod. V karibských SIDS tento ukazatel činil 10,9\%, u AIMS $12,0 \% \mathrm{a} v$ tichomořské oblasti $8,9 \%$ (WTTC 2018). Je však nutné zdůraznit, že uvedené regionální průměry jsou nevážené populací - např́klad u AIMS jsou tyto statistiky výrazně ovlivňovány vysokými hodnotami Malediv, Seychel, ale i Kapverd. Průměry pro jednotlivé geografické regiony navíc zastírají vysokou vnitřní heterogenitu zmíněných ukazatelů mezi jednotlivými státy. Z tabulky 2 , která zachycuje př́imý podíl turismu na HDP, respektive př́mý podíl na zaměstnanosti pro individuální SIDS, je zřejmé, že význam turistického ruchu pro ekonomický růst a zaměstnanost se mezi jednotlivými SIDS značně liší. Zatímco přímý podíl cestovního ruchu na tvorbě HDP přesáhl v roce $2016 \mathrm{v}$ př́ípadě Malediv $40 \%$, v případě Kuby činil podíl 2,2 \% (WTTC 2018). Podobné rozpětí hodnot můžeme pozorovat také pro prímý podíl na zaměstnanosti, který v roce 2016 činil u Aruby 31,3\%, zatímco v prŕípadě již zmíněné Kuby jen $2,1 \%$. Z tab. 2 je patrné, že v individuálních př́ípadech může být prínos turismu významným motorem ekonomického rozvoje. Podle UNWTO (2014) umožnil ekonomický růst založený na turistickém ruchu opustit ostrovním státům Samoa, Kapverdy a Maledivy skupinu Nejméně rozvinutých zemí (LDCs). Kromě turistického ruchu se ekonomiky SIDS orientují na rybolov a zemědělství (produkce a export tropických plodin, např. citrusů, banánů, kokosových ořechů, cukrové třtiny a výrobků z nich), některé také na těžební průmysl (např. těžba ropy ve státech Trinidad a Tobago a Bahrajn, těžba niklové rudy na Nové Kaledonii či fosfátů na Nauru) - UN-OHRLLS (2011).

Z hlediska převažujících atraktivit jsou malé ostrovní rozvojové státy dominantně př́mořskými destinacemi. Výjimku v tomto ohledu tvoří Singapur a Bahrajn, které jsou typickými městskými destinacemi. Atraktivita př́mořského cestovního ruchu je dána kombinací tří „,S“, tj. „sun, sea and sand“ (Graci a Dodds 2010). Přímořský turismus v SIDS tvoř́i dominantní část aktivit a jen v menší míře je doplněn o další atraktivity (historická města a kulturní pamětihodnosti); (Patullo 2005 a Cameron a Gatewood 2008).

Cestovní ruch, zvláště pak jeho masová forma, s sebou pro SIDS přináší vedle ekonomických přínosů také nežádoucí ekonomické, sociální a environmentální dopady. Př́liš velká návštěvnost může podle Fialové a Nekolného (2015) vést k poškozování přírodních i kulturních atraktivit a snižovat vlastní zážitek z navštívené destinace a v konečném důsledku zapříčiňovat ostrovním destinacím ekonomickou ztrátu. Tab. 3, která prezentuje podíl počtu př́ijezdů mezinárodních turistů v přepočtu na jednoho obyvatele destinací pro rok 2016 (World Bank 2018a), odhaluje, že mezi turisticky zatížené patří zejména karibské SIDS (v průměru 3,2 turistických prŕijezdů na obyvatele), následované AIMS (v průměru 2,0 turistických př́jezdů na obyvatele) a tichomořskými SIDS (v průměru 1,68 turistických prŕíjezdů na obyvatele). Mezi pěti ostrovními destinacemi s nejvyšším počtem př́ijezdủ na obyvatele se nacházejí Britské panenské ostrovy (13,31 prŕjezdů na obyvatele), Turks a Caicos (13,01 př́ijezdů na obyvatele) a Aruba (10,51 př́ijezdů na obyvatele) v Karibské oblasti, Severní Mariany (9,65 př́ijezdů na obyvatele) a Guam $(9,42$ př́ijezdů na obyvatele) v Tichém oceánu. 
Tab. 2. Malé ostrovní rozvojové státy dle přímého podílu cestovního ruchu na tvorbě HDP a prŕmého podílu cestovního ruchu na zaměstnanosti (2016)

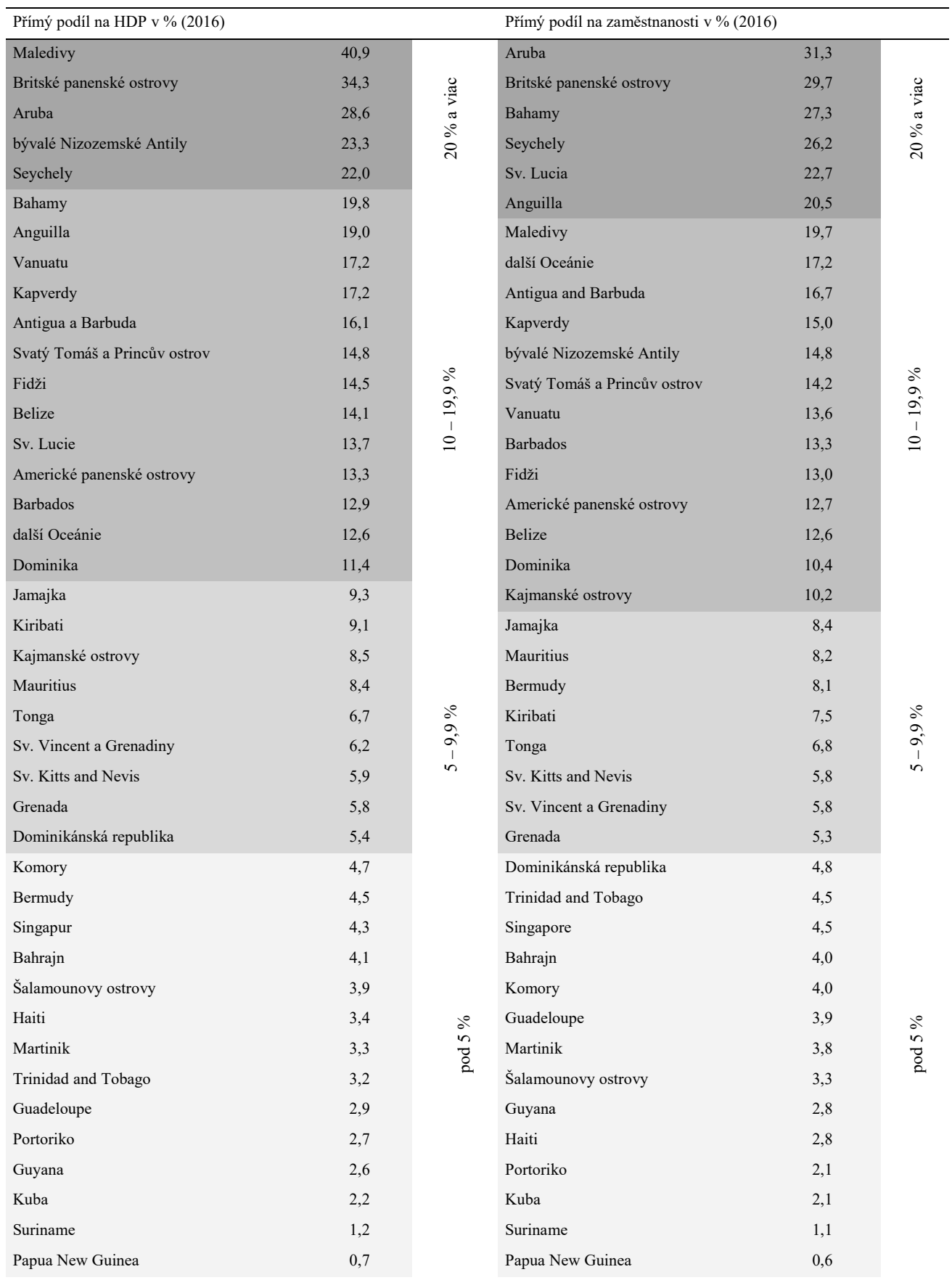

Zdroj: autoři na základě dat WTTC (2018). 
Tab. 3. Podíl počtu př́ijezdů do malých ostrovních rozvojových států na obyvatele (2016)

\begin{tabular}{lrlr}
\hline Britské panenské ostrovy & 13,31 & Turks a Caicos & 13,01 \\
Aruba & 10,51 & Severní Mariany & 9,65 \\
Guam & 9,42 & Bahrajn & 7,13 \\
Palau & 6,42 & Kajmanské ostrovy & 6,34 \\
Americké panenské ostrovy & 6,24 & & 3,73 \\
\hline Bahamy & 3,79 & Bermudy & 3,08 \\
Seychely & 3,20 & Maledivy & 2,62 \\
Curaçao & 2,76 & Antigua a Barbuda & 2,23 \\
Singapur & 2,30 & Svatý Kryštof a Nevis & 1,95 \\
Barbados & 2,22 & Svatá Lucie & 1,11 \\
Grenada & 1,45 & Kapverdy & 1,06 \\
Portoriko & 1,10 & Dominika & 1,01 \\
Belize & 1,05 & Mauricius & 0,76 \\
\hline Fidži & 0,88 & Jamajka & 0,69 \\
Svatý Vincenc a Grenadiny & 0,72 & Samoa & 0,56 \\
Francouzská Polynésie & 0,69 & Dominikánská republika & 0,46 \\
Tonga & 0,55 & Suriname & 0,36 \\
New Kaledonie & 0,42 & Americká Samoa & 0,35 \\
Vanuatu & 0,35 & Kuba & 0,30 \\
Guyana & 0,30 & Trinidad and Tobago & 0,23 \\
Mikronésie (Federativní státy) & 0,28 & Tuvalu & 0,15 \\
Marshallovy ostrovy & 0,18 & Svatý Tomáš a Princův ostrov & 0,05 \\
\hline Východní Timor & 0,05 & Kiribati & 0,04 \\
Haiti & 0,05 & Śalamounovy ostrovy & 0,02 \\
Komory & 0,03 & Guinea-Bissau & 0,02 \\
Papua Nová Guinea & 0,02 & Nauru & \\
\hline
\end{tabular}

Poznámka: V tabulce jsou od sebe odděleny státy s podílem turistů na počet obyvatel vyšším než 5 , v intervalu 1 až 5 , $\mathrm{v}$ intervalu 0,1 až 1 , menším než 0,1 .

Zdroj: autoři na základě dat World Bank (2018a).

Přes význam turistického ruchu pro malé ostrovní rozvojové státy existuje jen omezené množství studií zaměřených na tuto oblast. Nejvýznamnějším zdrojem informací a dat jsou mezinárodní organizace, zejména UNWTO a UN-OHRLLS. Odborné články v akademických žurnálech se této oblasti nevěnují, např. zvláštní číslo prestižního časopisu The Journal of Development Studies (Fragility and Development in Small Island Developing States 2010) neobsahuje žádný článek specificky věnovaný problematice cestovního ruchu. Akademické články zabývající se SIDS mají tendenci soustředit se na problematiku klimatických změn a přírodních rizik (viz např. Pelling and Uitto 2001, Turvey 2007, Kelman and West 2009 a Mercer et al. 2012). Cestovnímu ruchu a jeho managementu se věnují př́ípadové studie zaměřené na jednotlivé ostrovní turistické destinace (např. Pipike 2012 pro Tuvalu a Papuu Novou Guineu, Venegas a Croes 2003 pro Arubu, Cañizares et al. 2015 pro Kapverdy aj.), jejich výstupy však nelze z důvodu rozdílných metodologických přístupů prímo porovnávat a generalizovat. Výjimkou z uvedeného jsou studie autorů Archibalda et al. (2008) a Laframboise et al. (2014), jejich výzkumy faktorů ovlivňující cestovní ruch se však omezují na ostrovy v Karibiku. Cílem tohoto článku je analyzovat determinanty cestovního ruchu celou skupinu Malých ostrovních rozvojových států. V tomto kontextu SIDS dosud nebyly řešeny, výzkum proto prrispívá $\mathrm{k}$ poznání předpokladů rozvoje této málo známé, ale nikoliv nevýznamné skupiny zemí. 


\section{DETERMINANTY CESTOVNÍHO RUCHU V MALÝCH OSTROVNÍCH ROZVOJOVÝCH STÁTECH}

Cílem studie je zjistit, jaké faktory mají vliv na př́lliv turistů do malých ostrovních států (SIDS). K tomuto účelu byla využita regresní analýza panelových dat pro období 2005 - 2016. Tento prŕstup se v literatuře zabývající se cestovním ruchem vyskytuje (Tasci 2007, Cho 2010 a Valek et al. 2014), nikoliv však v aplikaci na SIDS. Problémem, který je v této souvislosti zjevný, je obtížný př́ístup k datům a poměrně omezený počet pozorování (k SIDS je řazeno 58 zemí s málo dostupnými statistikami). Data k většině proměnných byla získána $\mathrm{z}$ databází mezinárodních organizací a dalších zdrojů, které jsou popsány v následující části článku.

Závislou proměnnou v analýze je počet turistů v jednotlivých SIDS za každý rok uvedeného období. Data pro tuto proměnnou byla získána ze zdroje World Bank (2018a). Údaje pro Nauru, kam ročně přijíždí zanedbatelný počet turistů, nebyly $\mathrm{k}$ dispozici $\mathrm{v}$ rámci žádných oficiálních statistik, proto byly aproximovány hodnotou ze zdroje Garfors (2012). Proměnná vstupuje do regresní analýzy ve zlogaritmované podobě (ln_arrivals). Nezávislé proměnné byly vybrány na základě rešerše literatury, která se zabývá vlivem různých faktorů na oblíbenost destinace u turistů (Pearce 2001, Hampton 2007, Prebežac a Mikulić 2008, Gay 2012, Prideaux a McNamara 2012, Lohmann a Beer 2013, Armstrong a Read 2014, Sharpley 2014 a Toader et al. 2014). Za velmi relevantní zdroj lze považovat zejména studii Cho (2010), která využívá data ze 135 zemí světa v regresní analýze ke stanovení faktorů ovlivňujících turistickou poptávku.

Nezávislé proměnné, které používáme k vysvětlení počtu turistů v SIDS, jsou následující:

- Proměnná 1: Velikost území jednotlivých SIDS. Data byla získána z World Bank (2018a). Tato proměnná vstupuje do regresního modelu v logaritmické podobě (ln_area). Předpokládáme, že rozlohou větší SIDS budou mít větší kapacitu pojmout více zahraničních turistů.

- Proměnná 2: Izolace. Proměnná izolace by měla aproximovat odlehlost, potažmo dostupnost a cenové náklady, které je potřeba vynaložit při cestě do daného státu/teritoria. Izolace byla měřena podle indexu izolace, jehož hodnota byla převzata ze zdroje UNEP (1998) vždy pro hlavní ostrov dané země (tedy pro ostrov, na kterém se nachází hlavní město). Index izolace se měří na základě vzdálenosti ostrova od nejbližšího sousedního ostrova, souostroví a kontinentu. V literatuře obecně panuje názor, že odlehlost ostrovů má negativní vliv na počet turistů v zemi (Cho 2010, Lohmann a Beer 2013, Karampela 2014 a Poirine 2014). Někteří autoři však považují odlehlost ostrova v souvislosti s turismem za atraktivní vlastnost, protože evokuje exotiku (Scheyvens a Russell 2011). Proměnná vstupuje do regresní analýzy v logaritmické podobě ( $l n \_$isolation).

- Proměnná 3: Hrubý domácí produkt na obyvatele, přepočtený podle parity kupní síly v dolarech (konstantní ceny 2011). V naší analýze tato proměnná aproximuje ekonomickou a sociální vyspělost dané destinace. Data pochází z World Bank (2018a). Předpokládáme, že vztah mezi touto proměnnou a závislou proměnnou bude pozitivní (vyšší ekonomická vyspělost by měla mít kladný vliv na př́liv mezinárodních turistů). Vzhledem $\mathrm{k}$ velké závislosti ekonomik některých SIDS na cestovním ruchu je však možné předpokládat i opačnou kauzalitu (počet turistů může mít vliv na HDP ostrovních destinací), proto bude proměnná do regrese vstu- 
povat s hodnotami zpožděnými o jeden rok; současně bude logaritmicky transformována (L1.ln_gdppc).

- Proměnná 4: Počet deštivých dnů (wetdays). Tato proměnná je zaměřená na klimatické poměry a počasí v destinaci. Údaje byly získány ze stránek Tyndall Centre for Climate Change and Research (2003). Proměnnou v modelech používáme v logaritmicky transformované podobě (ln_wetdays) a předpokládáme, že její vliv na závislou proměnnou bude negativní, tj., že počet mezinárodních turistů bude klesat s vyšším počtem deštivých dnů v destinacích.

- Proměnná 5: Index politické stability a absence násilí/terorismu (polstab). Politická stabilita je důležitým faktorem př́livu turistů do země (Sharpley 2014). Např́klad na Fidži byl zaznamenán jasný pokles počtu turistů v souvislosti s nepokoji v roce 2006 (Scheyvens a Russell 2011). Index je měřen na škále od přibližně $-2,5$ (nejnižší míra politické stability) do 2,5 (nejvyšší míra politické stability). Hodnoty pro jednotlivé SIDS byly převzaty ze zdroje World Bank (2018b). Očekáváme pozitivní vztah mezi touto proměnnou a závislou proměnnou.

- Proměnná 6: Počet vražd na 100000 obyvatel v destinaci. Tato proměnná aproximuje bezpečnostní situaci v zemi z hlediska běžnějších forem kriminality (ve srovnání s výše uvedenou proměnnou polstab). Horší bezpečnostní situace v zemi může být důvodem nižšího počtu turistů (jak uvádí např. Pipike $2012 \mathrm{v}$ případě Papuy Nové Guiney). Očekáváme negativní vztah mezi počtem vražd a počtem mezinárodních turistů. Hodnoty pro proměnnou, která do analýzy vstupuje v logaritmické transformaci (ln_homic), byly čerpány z World Bank (2018a).

- Proměnná 7: Národní cenová hladina, standardně aproximována konverzním faktorem parity kupní síly (podíl konverzního faktoru parity kupní síly a tržního směnného kurzu). Tato proměnná ř́ká, kolik dolarů v určité zemi je potřeba ke koupi zboží, které je ve Spojených státech amerických možné koupit za jeden dolar. Cenová hladina $\mathrm{v}$ destinaci je důležitým faktorem ve vztahu k počtu turistů (Gay 2012 a Toader et al. 2014). Data byla získána z World Bank (2018a); do regrese vstupuje proměnná ve zlogaritmované podobě (ln_price). Předpokládáme negativní vliv proměnné na závislou proměnnou, tedy její vyšší hodnoty (vyšší národní cenová hladina) budou asociovány s nižším př́livem mezinárodních turistů.

- Proměnná 8: Přístup ke zlepšeným sanitačním zařízením. Tato proměnná, měřená podílem populace $\mathrm{s}$ přístupem k sanitačním zařízením s vyšší kvalitou, aproximuje hygienické podmínky v destinacích, které mohou významně ovlivňovat mezinárodní cestovní ruch. Proměnnou v modelech používáme v logaritmicky transformované podobě (ln_sanit) a předpokládáme, že její vliv na závislou proměnnou bude pozitivní, tedy že s lepšími hygienickými podmínkami počet mezinárodních turistů poroste. Data pochází z World Bank (2018a).

- Proměnná 9: Počet pokojů v turistických zařízeních. Proměnná aproximuje rozvinutost infrastruktury cestovního ruchu v destinacích, která by měla pozitivně ovlivňovat množství turistických př́ijezdů. Je však možné předpokládat i opačnou kauzalitu (rozvinutost infrastruktury je vyšší, protože do destinace jezdí více turistů), proto bude proměnná do regrese vstupovat $\mathrm{s}$ hodnotami zpožděnými o jeden rok. Data pro proměnnou, kterou používáme ve zlogaritmované podobě (ln_rooms), jsme čerpali z databáze UNWTO (2016), ve které však byla data dostup̄ná pouze po rok 2014. Tato skutečnost výrazně snížila počet pozorování, proto jsme proměnnou ln_rooms zařadili pouze do jednoho z našich modelů. 


\section{MODELY, ODHADY A VÝSLEDKY}

Pro námi zvolenou regresní analýzu panelových dat používáme metodu náhodných efektů (random_effects method, RE), a to především z toho důvodu, že pracujeme s několika časově konstantními proměnnými, jejichž vliv na závislou proměnnou nelze alternativní metodou fixních efektů odhadnout. Sestavili jsme celkem pět regresních modelů, přičemž počet pozorování v jednotlivých modelech se významně liší podle toho, jaké proměnné $\mathrm{v}$ nich používáme (například použití proměnných ln_homic a/nebo ln_rooms významně snižuje počet pozorování v př́slušných modelech). Použité proměnné byly do regresní analýzy zařazeny na základě teorie a dř́ive provedených empirických výzkumů v oblasti cestovního ruchu (viz předchozí část textu). Základní model (model 2) má následující podobu:

$$
\begin{aligned}
& (\text { In_arrivals })=\alpha+\beta_{1}(\text { In_isolation })+\beta_{2}(\text { ln_wetdays })+\beta_{3}(\text { In_area }) \\
& +\beta_{4}(\text { L1.ln_gdppc })+\beta_{5}(\text { ln_sanit })+\beta_{6}(\text { polstab })+\varepsilon .
\end{aligned}
$$

$\mathrm{V}$ rovnici je $\alpha$ koeficient pro průsečík, $\beta_{1}-\beta_{6}$ jsou regresní koeficienty našeho zájmu (měřící vliv příslušné vysvětlující proměnné na závislou proměnnou, ceteris paribus) a $\varepsilon$ je chybová složka v regresi. Předpona „ln_ “ značí, že proměnné vstupovaly do regrese ve zlogaritmované podobě. Označení „L1.“ znamená, že hodnoty proměnné byly v regresní analýze o jedno období (rok) zpožděné.

Proměnné do základního modelu byly vybrány takto: proměnnou ln isolation aproximujeme faktor odlehlosti, potažmo dostupnosti či cenových nákladū, které je potřeba vynaložit při cestě do dané destinace. Proměnná ln_wetdays aproximuje klimatické podmínky v destinaci, zatímco ln_area je kontrolní proměnná, jejíž pomocí kontrolujeme kapacitu destinace přjímā zahraniční turisty. Ekonomická a sociální rozvinutost teritoria je aproximována proměnnou HDP na obyvatele. Abychom předešli problému potenciální oboustranné kauzality (a tedy i endogenity $\mathrm{v}$ odhadech), používáme $\mathrm{v}$ regresi hodnoty proměnné zpožděné o jeden rok $\left(L 1 . l n \_g d p p c\right)$. Do základního modelu vstupují další dvě proměnné: ln_sanit aproximujeme hygienické podmínky v destinacích a polstab měríme politickou stabilitu a absenci násilí (terorismu).

Zatímco v modelu 1 vynecháváme $\mathrm{z}$ analýzy proměnnou polstab, $\mathrm{v}$ modelech 3 až 5 přidáváme do analýzy další proměnné, které by podle teorie měly mít vliv na příliv mezinárodních turistů do destinací. V modelu 3 jsou přidány bezpečností faktory (ln_homic), v modelu 4 navíc národní cenová hladina (ln_price). V modelu 5 přidáváme proměnnou aproximující rozvoj turistické infrastruktury (ln rooms). Vzhledem $\mathrm{k}$ omezenému počtu pozorování pro tuto proměnnou jsme byli nuceni $\mathrm{z}$ modelu odstranit ln_homic a ln_price, nebot' počet pozorování by v jejich přítomnosti dále významně poklesl. V souvislosti s proměnnou ln_rooms je evidentní problém oboustranné kauzality (a tedy i endogenity), proto v regresi používáme hodnoty proměnné zpožděné o jeden rok (L1.ln_rooms). Výsledky regresí pro všechny modely jsou uvedeny $v$ tab. 4.

Všechny proměnné v základním modelu mají očekávaný směr a jsou statisticky významné alespoň na pětiprocentní hladině významnosti, což potvrzuje naše očekávání. Tyto výsledky lze považovat za robustní, nebot' platí ve všech modelech, s výjimkou proměnné polstab, která je významná pouze v základním modelu. Za poklesem její (nižší) statistické významnosti však může stát také pokles pozorování, ke kterému v modelech 3 až 5 (ve srovnání s modelem 2) dochází. Z dodatečně analyzovaných proměnných je statisticky významná pouze proměnná ln_rooms, 
všechny proměnné však mají očekávaný směr působení na závislou proměnnou. Také hodnoty koeficientu determinace $\mathrm{R}^{2}$ jsou ve všech modelech vysoké. Výsledky regresních analýz jsou zevrubněji diskutovány a shrnuty v následující sekci.

Tab. 4. Modely a výsledky regresní analýzy

\begin{tabular}{|c|c|c|c|c|c|}
\hline \multicolumn{6}{|c|}{ Závislá proměnná: ln_arrivals } \\
\hline & model 1 & model 2 & model 3 & model 4 & model 5 \\
\hline & $\mathrm{RE}$ & $\mathrm{RE}$ & $\mathrm{RE}$ & $\mathrm{RE}$ & $\mathrm{RE}$ \\
\hline ln_isolation & $\begin{array}{c}-0,706^{* * *} \\
(0,234)\end{array}$ & $\begin{array}{c}-0,715^{* * *} \\
(0,233)\end{array}$ & $\begin{array}{c}-0,875^{* * *} \\
(0,209)\end{array}$ & $\begin{array}{c}-0,864 * * * \\
(0,207)\end{array}$ & $\begin{array}{c}-0,298^{* *} \\
(0,128)\end{array}$ \\
\hline ln_wetdays & $\begin{array}{c}-0,822 * * * \\
(0,212)\end{array}$ & $\begin{array}{c}-0,883 * * * \\
(0,230)\end{array}$ & $\begin{array}{c}-0,863 * * * \\
(0,233)\end{array}$ & $\begin{array}{c}-0,857 * * * \\
(0,234)\end{array}$ & $\begin{array}{c}-0,730 * * * \\
(0,236)\end{array}$ \\
\hline ln_area & $\begin{array}{c}0,725 * * * \\
(0,103)\end{array}$ & $\begin{array}{c}0,741 * * * \\
(0,107)\end{array}$ & $\begin{array}{c}0,715 * * * \\
(0,105)\end{array}$ & $\begin{array}{c}0,713 * * * \\
(0,103)\end{array}$ & $\begin{array}{c}0,261 * * * \\
(0,091)\end{array}$ \\
\hline L1.ln_gdppc & $\begin{array}{c}0,796 * * * \\
(0,210)\end{array}$ & $\begin{array}{c}0,806 * * * \\
(0,214)\end{array}$ & $\begin{array}{c}0,632 * * \\
(0,270)\end{array}$ & $\begin{array}{c}0,638 * * \\
(0,270)\end{array}$ & $\begin{array}{c}0,553 * * * \\
(0,121)\end{array}$ \\
\hline ln_sanit & $\begin{array}{c}2,119 * * * \\
(0,462)\end{array}$ & $\begin{array}{c}2,050 * * * \\
(0,470)\end{array}$ & $\begin{array}{c}1,913 * * \\
(0,837)\end{array}$ & $\begin{array}{c}1,913 * * \\
(0,817)\end{array}$ & $\begin{array}{l}1,054 * * \\
(0,437)\end{array}$ \\
\hline polstab & - & $\begin{array}{c}0,128 * * \\
(0,060)\end{array}$ & $\begin{array}{c}0,086 \\
(0,061)\end{array}$ & $\begin{array}{c}0,094 \\
(0,064)\end{array}$ & $\begin{array}{c}0,086 \\
(0,065)\end{array}$ \\
\hline ln_homic & - & - & $\begin{array}{l}-0,017 \\
(0,035)\end{array}$ & $\begin{array}{l}-0,016 \\
(0,036)\end{array}$ & - \\
\hline In_price & - & - & - & $\begin{array}{c}-0,090 \\
(0,193)\end{array}$ & - \\
\hline L1.ln_rooms & - & - & - & - & $\begin{array}{c}0,583 * * * \\
(0,115)\end{array}$ \\
\hline konstanta & $\begin{array}{l}-2,611 \\
(1,879)\end{array}$ & $\begin{array}{l}-2,248 \\
(2,029)\end{array}$ & $\begin{array}{c}0,656 \\
(3,381)\end{array}$ & $\begin{array}{c}0,498 \\
(3,293)\end{array}$ & $\begin{array}{c}0,875 \\
(2,219)\end{array}$ \\
\hline Celkové $\mathrm{R}^{2}$ & 0,847 & 0,8400 & 0,805 & 0,806 & 0,921 \\
\hline Vnitroskupinové $\mathrm{R}^{2}$ & 0,313 & 0,339 & 0,218 & 0,217 & 0,536 \\
\hline Meziskupinové $\mathrm{R}^{2}$ & 0,858 & 0,851 & 0,852 & 0,854 & 0,940 \\
\hline Wald chi $^{2}$ & $288,67 * * *$ & $287,40 * * *$ & $207,84 * * *$ & $235,83 * * *$ & $364,25 * * *$ \\
\hline Počet pozorování & 266 & 266 & 164 & 164 & 178 \\
\hline Počet skupin & 30 & 30 & 30 & 30 & 25 \\
\hline
\end{tabular}

Poznámka: Regresní koeficienty jsou statisticky významné na *** $1 \%$ hladině významnosti, ** $5 \%$ hladině významnosti, * $10 \%$ hladině významnosti. Čísla uvedená v závorkách jsou směrodatné chyby robustní vưči heteroskedasticitě (použita Whiteova metoda).

\section{SHRNUTÍ A DISKUSE VÝSLEDKŮ ANALÝZ}

Z provedené regresní analýzy vyplývá, že hlavními determinanty př́ilivu turistů do SIDS jsou odlehlost, resp. dostupnost ostrovních destinací (proměnná ln_isolation), klima (proměnná ln_wetdays), velikost země (proměnná ln_area), úroveň ekonomické vyspělosti (proměnná $\ln g d p p c$ ) a hygienické podmínky v zemi (proměnná ln_sanit). Mezi další statisticky významné proměnné patří politická stabilita (proměnná polstab) a úroveň turistické infrastruktury (proměnná ln_rooms). Ostatní testované faktory, tedy úroveň národní cenové hladiny (proměnná $\ln$ _price) a bezpečnost $\mathrm{z}$ hlediska běžnějších forem kriminality 
(proměnná ln_homic), nejsou statisticky významné, nicméně mají očekávaný směr vlivu na vysvětlovanou proměnnou.

Negativní vliv proměnné $l n$ isolation na počet příchozích turistů není překvapující, potvrdil napřr. názor autorů Cho (2010), Lohmann a Beer (2013), Poirine (2014) a Karampela (2014) i náš předpoklad. Cím méně jsou SIDS izolované (resp. čím více jsou dostupné), tím více turistů do nich proudí. Naopak horší dostupnost ostrovům z hlediska cestovního ruchu neprospívá. Analýza potvrdila i důležitost klimatických vlivů, přičemž proměnná ln_wetdays měla podle očekávání negativní vliv (tedy čím více deštivých dnů, tím méně turistů v ostrovních destinacích). Podle očekávání se též ukázalo, že rozlohou větší SIDS mají větší kapacitu přijímat mezinárodní turisty. Proměnná ln_area je ve všech modelech signifikantní a má pozitivní vliv na závislou proměnnou. Úroveň ekonomické vyspělosti (aproximována proměnnou $\ln g d p p c$ ) úzce souvisí s rozvinutostí obecné infrastruktury a služeb, které jsou pro cestovní ruch důležité. Provedená analýza tento výsledek potvrzuje, nebot' regresní koeficient pro tuto proměnnou byl ve všech modelech pozitivní a statisticky významný. Také hygienické či zdravotní podmínky v destinaci jsou důležitým faktorem prŕlivu zahraničních turistů - proměnná ln_sanit je pozitivní a statisticky významná. Horší hygienické podmínky v destinacích turisty odstrašují, naopak lepší v průměru lákají.

Politická stabilita a absence násilí (terorismu) je v prostředí SIDS méně významným faktorem cestovního ruchu. Proměnná polstab je sice vždy pozitivní (vyšší politická stabilita vede k vyššímu počtu turistů), ale tento vztah je významný pouze $\mathrm{v}$ našem základním modelu. $\mathrm{V}$ ostatních modelech je vliv proměnné těsně statisticky nevýznamný. Jedním z důvodů může být skutečnost, že většina SIDS $\mathrm{v}$ posledních letech patři mezi politicky relativně stabilnější destinace, resp. že pro méně stabilní destinace nejsou k dispozici data, což je automaticky vylučuje z analýzy. Tento závěr může naznačovat i fakt, že proměnná polstab je nevýznamná právě v modelech, které jsou charakteristické výrazně nižším počtem pozorování, než model základní.

Pozitivním a statisticky významným determinantem př́livu turistů do ostrovních destinací je také úroveň rozvinutosti infrastruktury cestovního ruchu, kterou jsme aproximovali počtem pokojů v turistických zařizeních (proměnná ln_rooms). Kauzalita ve vztahu $\mathrm{k}$ počtu př́chozích turistů však může pro tuto proměnnou (podobně jako pro ln_gdppc) oboustranná. Lepší turistická infrastruktura může být faktorem (př́ičinou) většího příliv turistů, současně ale může být i jeho důsledkem (infrastruktura vzniká kvůli turistické poptávce). Abychom předešli problému endogenity $\mathrm{v}$ naší regresi $\mathrm{v}$ důsledku oboustranné kauzality, zpozdili jsme hodnoty této proměnné o jeden rok. Př́liv turistů v roce 2015 jsme vysvětlovali počtem pokojů v roce 2014 (počet pokojů v roce 2014 nemohl být počtem turistů v roce 2015 ovlivněn). Analogický postup jsme aplikovali také na proměnnou ln_gdppc.

Je zřejmé, že většina našich proměnných je statisticky významná, přičemž všechny mají námi očekávaný směr působení na závislou proměnnou. Také koeficienty determinace $\left(R^{2}\right)$ pro naše modely jsou vysoké. Ačkoliv jsou naše výsledky $\mathrm{v}$ tom smyslu relativně dobré, nejsou ideální. Kromě dříve uvedených důvodů to může být způsobeno i tím, že námi použitá metoda, stejně jako naše data, mají určité limity. Pokud jde o data, naprosto zásadní je jejich dostupnost pro malé ostrovní destinace, která je v některých př́ípadech velmi omezená. Pro některé SIDS pak data nejsou dostupná vůbec. 
Jiným typem omezení je skutečnost, že náš výzkum pracuje s daty pouze pro destinace. Do analýzy tak nemohly být zahrnuty faktory na straně zemí původu (například ekonomická vyspělost aproximující ekonomické možnosti turistů) či vzájemné vztahy mezi zeměmi původu a destinacemi (např́íklad podobnost jazyků, společný historicko-politický vývoj, vzájemná geografická vzdálenost apod.). Nezahrnutí těchto faktorů do analýzy může potenciálně vytvářet problém opomenutých proměnných, které mohou negativně ovlivňovat výsledky analýz.

Některé z těchto limitů by bylo možné částečně vyřešit zcela odlišným designem výzkumu, např́klad aplikací gravitačního modelu toků mezinárodních turistů mezi zeměmi původu a destinacemi (SIDS) s využitím bilaterálních panelových dat za určité časové období. K této formě výzkumu, která je však datově násobně náročnější, by pak bylo rovněž vhodné použít pokročilejších analytických metod, např́klad analýzu dynamických panelových dat.

\section{ZÁVĚR}

SIDS mají mnohé společné charakteristiky s ostatními rozvojovými zeměmi, nadto však čelí specifickým výzvám. Kromě malé rozlohy a geografické odlehlosti se jedná o malou surovinovou základnu, vysokou zranitelnost vủči vnějším ekonomickým šokům a dopadům klimatických změn. Zároveň platí, že pro malé ostrovní rozvojové státy má oceán a pobřeží strategický význam a tvoří potenciálně hodnotný zdroj pro rozvoj, který je zřetelný v oblasti turistického ruchu. Rešerší odborných textů (viz. např. Spenceley a Meyer 2012, Chou 2013 a UNWTO 2014) byl potvrzen pozitivní vliv turismu na rozvoj malých ostrovních států. Pomocí regresní analýzy byl dále zjištěn vliv konkrétních faktorů na počet turistů v SIDS. Těmito faktory jsou zejména dostupnost, klima a ekonomická vyspělost.

Je zřejmé, že lokální klima nemohou SIDS nijak reálně ovlivnit. Výsledky naznačují, že státy s menším počtem deštivých dnů (potažmo lepším klimatem) mají větší potenciál cestovního ruchu, a proto by se na něj měly zaměřit jako na svou rozvojovou př́iležitost. Naše zjištění také naznačují, že s vyšší ekonomickou vyspělostí poroste i počet turistů v SIDS. Je však nutné si uvědomit, že růst ekonomické úrovně zahrnuje mnohé ekonomické a společenské změny a jedná se o dlouhodobý proces, který mohou SIDS v krátkém období jen velmi obtížně urychlovat.

Naopak dostupnost je jedním z faktorů, který můžou SIDS významně a relativně rychle ovlivnit ve svůj prospěch. Rozvoj letecké infrastruktury, leteckých linek a ve specifických prŕípadech i námořní dopravy (včetně podpory př́íjezdů velkých zaoceánských turistických lodí) může významně navýšit počet mezinárodních turistů do malých ostrovních rozvojových států. Z regionálního hlediska mají v tomto směru nevýhodu zejména pacifické SIDS kvůli své velké izolovanosti a vysokým nákladům na přepravu. Podobně pozitivní vliv na př́ijezdy mezinárodních turistů v relativně krátkém období mohou mít zlepšené hygienické podmínky v destinacích a investice do turistické infrastruktury.

Závěrem je ovšem nutné také konstatovat, že samotný nárůst turistického ruchu neznamená jen rozvojovou prŕležitost, ale rovněž představuje riziko pro křehké ekosystémy a kulturní specifika SIDS. Proto malé ostrovní rozvojové státy zůstávají výzvou pro rozvoj udržitelného cestovního ruchu. 


\section{LITERATURA}

AOSIS (2015). About AOSIS, [Online]. Dostupné na: http://aosis.org/about/ [cit: 07-62017].

ARCHIBALD, X., LACORBINIÉRE, J., MOORE, W. (2008). Analysis of tourism competitiveness in the Caribbean: a gravity model approach. Paper presented at the 29th Annual Review Seminar, Central Bank of Barbados, [Online]. Dostupné na: http:// www.centralbank.org.bb/news/article/6650/analysis-of-tourism-competitiveness-in-thecaribbean-a-gravity-model-approach [cit: 12-5-2017].

ARMSTRONG, H. W., READ, R. (2014). The significance of geographic location in island studies: a rejoinder. Island Studies Journal, 9, 367-372.

BAAR, V. (2017). Bougainville: from conflict to independence under the law? In Riegel, M., Doboš, B., eds. Unrecognized states and secession in the 21st century. Berlin (Springer), pp. 169-186.

CAMERON, C. M., GATEWOOD, J. B. (2008). Beyond sun, sand and sea: the emergent tourism programme in the Turks and Caicos Islands. Journal of Heritage Tourism, 3, 5573.

CAÑIZARES, S. M. S., CANALEJO, A. M. C., TABALES, J. M. N. (2015). Stakeholders' perceptions of tourism development in Cape Verde, Africa. Current Issues in Tourism, 19, 966-980.

DUŠKOVÁ, L., HARMÁČEK, J., KRYLOVÁ, P., OPRŠAL, Z., SYROVÁTKA, M., ŠAFAŘÍKOVÁ, S. (2011). Encyklopedie rozvojových studií. Olomouc (Univerzita Palackého v Olomouci).

FIALOVÁ, D., NEKOLNÝ, L. (2015). Rub a líc turistické přitažlivosti. Geografické rozhledy, 4(14), 8-9.

Fragility and Development in Small Island Developing States (2010). The Journal of Development Studies, 46(5).

GARFORS, G. (2012). The 25 least visited countries in the world, [Online]. Dostupné na: http://www.garfors.com/2013/01/the-25-least-visited-countries-in-world.html. [cit: 17-5 $-2017]$.

GAY, J-C. (2012). Why is tourism doing poorly in overseas France? Annals of Tourism Research, 29, 1634-1652.

GRACI, S., DODDS, R. (2010). Sustainable tourism in island destinations. New York (Earthscan).

HAMPTON, M. (2007). Competing industries in islands: a new tourism approach. Annals of Tourism Research, 34, 998-1020.

HARMÁČEK, J. (2013). Teorie, realita a rozvojové souvislosti ekonomického ruistu v nejméně rozvinutých zemich (LDCs). Olomouc (Univerzita Palackého v Olomouci).

$\mathrm{CHO}, \mathrm{V}$. (2010). A study of the non-economic determinants in tourism demand. International Journal of Tourism Research, 12, 307-320.

CHOCK, S., MACBETH, J., WARREN, C. (2007). Tourism as a tool for poverty alleviation: a critical analysis of 'Pro-Poor Tourism' and implications for sustainability. Current Issues in Tourism, 10, 144-165.

CHOU, M. C. (2013). Does tourism development promote economic growth in transition countries? A panel data analysis, Economic Modelling, 33, 226-232.

KARAMPELA, S. (2014). Accessibility of islands: towards a new geography based on transportation modes and choices. Island Studies Journal, 9, 293-306.

KELMAN, I., WEST, J. J. (2009). Climate change and Small Island Developing States: a critical review. Ecological and Environmental A nthropology, 5, 1-16.

LAFRAMBOISE, N., MWASE, N., PARK, J., ZHOU, Y. (2014). Revisiting tourism flows to the Caribbean: what is driving arrivals? IMF Working Paper. WP/14/229, [Online]. Dostupné na: https://www.imf.org/external/pubs/ft/wp/2014/wp14229.pdf. [cit: 18-52017]. 
LOHMANN, M., BEER, H. (2013). Fundamentals of tourism: what makes a person a potential tourist and a region a potential tourism destination? Economics and Business Review EBR, 13(4), 83-97.

MERCER, J., KELMAN, I., ALFTHAN, B., KURVITS, T. (2012). Ecosystem-based adaptation to climate change in Caribbean Small Island Developing States: integrating local and external knowledge. Sustainability, 4, 1908-1932.

OPRSAL, Z. (2014). Mezinárodni rozvojová spolupráce: vybrané aspekty. Olomouc (Univerzita Palackého v Olomouci).

PATTULLO, P. (2005). Last resorts: the cost of tourism in the Caribbean. New York (Monthly Review Press).

PEARCE, D. G. (2001). Tourism and peripherality: perspectives from Asia and the South Pacific. Tourism and Hospitability Research, 3, 295-309.

PELLING, M., UITTO, J. (2001). Small Island Developing States: natural disaster vulnerability and global change. Global Environmental Change Part B: Environmental Hazards, $3(2), 49-62$.

PIPIKE, J. K. (2012). Comparative study between Fiji and Papua New Guinea tourism development: Lessons to learn from Fiji. Procedia - Social and Behavioral Sciences, 65, 192-198.

POIRINE, B. (2014). The significance of geographic location in island studies: a rejoinder. Island Studies Journal, 9, 373-376.

PREBEŽAC, D., MIKULIC, J. (2008). Destination image and key drivers of perceived destination attractiveness. Trziste/Market. 10, 163-178.

PRIDEAUX, B., McNAMARA, K. E. (2012). Turning a global crisis into a tourism opportunity: the perspective from Tuvalu. International Journal of Tourism Research, 15, 583594.

SHARPLEY, R. (2014). Tourism and governance in Small Island Developing States (SIDS): the case of Zanzibar. International Journal of Tourism Research, 16, 87-96.

SCHEYVENS, R., MOMSEN, J. H. (2008). Tourism and poverty reduction: issues for Small Island States. Tourism Geographies, 10, 22-41.

SCHEYVENS, R., RUSSELL, M. (2011). Tourism and poverty alleviation in Fiji: comparing the impacts of small- and largescale tourism enterprises. Journal of Sustainable Tourism, 20, 417-436.

SPENCELEY, A., MEYER, D. (2012). Tourism and poverty reduction: theory and practice in less economically developed countries. Journal of Sustainable Tourism, 20, 297-317.

TASCI, A. D. A. (2007). Assessment of factors influencing destination image using a multiple regression model. Tourism Review, 62(2), 23-30.

TOADER, C-S., BRAD, I., SÂMBOTIN, D., HURMUZACHE, T. C., MARTIN, S. C. (2014). Aspects regarding factors that contribute to the choice of tourism destination. Lucrări Științifice Management Agricol, 16, 140-143.

TURVEY, R. (2007). Vulnerability assessment of developing countries: the case of Small Island Developing States. Development Policy Review, 25, 243-262.

TYNDALL CENTRE FOR CLIMATE CHANGE AND RESEARCH. (2003). Data, [Online]. Dostupné na: http://www.cru.uea.ac.uk/ timm/cty/obs/TYN CY 1 1.html [cit: 06-11-2016].

UN (2014). Report of the global conference on the sustainable development of Small Island Developing States, Bridgetown, Barbados, 25 April-6 May 1994. United Nations General Assembly, A/CONF.167/9, [Online]. Dostupné na: http://www.un.org/esa/dsd/ dsd aofw sids/sids pdfs/BPOA.pdf. [cit: 08-12-2016].

UN (2015). International year of sustainable tourism for development, 2017. A/C.2/70/L.5/ Rev.1., [Online]. Dostupné na: http://undocs.org/A/C.2/70/L.5/Rev.1 [cit: 03-02-2017].

UNEP (1998). Island directory. Basic environmental and geographic information on the significant islands of the world, [Online]. Dostupné na: http://islands.unep.ch/isldir.htm [cit: 25-10-2016]. 
UN-OHRLLS (2011). Small Island Developing States: Small Islands Big(ger) Stakes, [Online]. Dostupné na: http://unohrlls.org/custom-content/uploads/2013/08/SIDS-Small -Islands-Bigger-Stakes.pdf [cit: 13-02-2017].

UN-OHRLLS (2017). Small Island Developing Places. Country profiles, [Online]. Dostupné na: http://unohrlls.org/about-sids/country-profiles/ [cit: 10-7-2017].

UNWTO (2014). Tourism in Small Island Developing States (SIDS). Building a more sustainable future for the people of Islands. Madrid: World Tourism Organization, [Online]. Dostupné na: http://cf.cdn.unwto.org/sites/all/files/docpdf/unwto tourisminsidsa4wtables.pdf [cit: 12-6-2017].

UNWTO (2016). The compendium of tourism statistics (1995 - 2014). Excel Datasheets on CD-ROM. Madrid (World Tourism Organization).

UNTWO (2017). UNWTO Annual Report 2016. Madrid (World Tourism Organization).

VALEK, N., SHAW, M., BEDNARIK, J. (2014). Socio-demographic characteristics affecting sport tourism choices: A structural model. Acta Gymnica, 44, 57-65.

VANEGAS SR, M., CROES, R. R. (2003). Growth, development and tourism in a small economy: evidence from Aruba. International Journal of Tourism Research, 5, 315-330.

WEAVER, D. B. (1998). Peripheries of the periphery. Tourism in Tobago and Barbuda. Annals of Tourism Research, 25, 292-313.

WEF (2017). The travel \& tourism competitiveness report 2017: Paving the way for a more sustainable and inclusive future, [Online]. Dostupné na: http://www3.weforum.org/ docs/WEF TTCR 2017 web 0401.pdf [cit: 03-02-2017].

WORLD BAN̄K (2018a). World̄ development indicators, [Online]. Dostupné na: http:// data.worldbank.org/indicator [cit: 25-02-2018].

WORLD BANK (2018b). Worldwide governance indicators, [Online]. Dostupné na: http:// info.worldbank.org/governance/wgi/index.aspx\#reports [cit: 23-02-2018].

WTTC (2017). World travel \& tourism council: travel \& tourism global economic impact \& issues 2017 - March 2017, [Online]. Dostupné na: https://www.wttc.org/-/media/ files/reports/economic-impact-research/2017-documents/global-economic-impact-andissues-2017.pdf [cit: 03-02-2017].

WTTC (2018). World travel \& tourism council data gateway, [Online]. Dostupné na: https://tool.wttc.org/ [cit: 20-02-2018].

\section{Zdeněk Opr ša l, Jaromír Ha r má č e k}

\section{GEOGRAPHIC, ENVIRONMENTAL AND SOCIO-ECONOMIC DETERMINANTS OF TOURISM IN SMALL ISLAND DEVELOPING STATES (SIDS)}

The Small Island Developing States (SIDS) group was established in 1992 at the United Nations Conference on Environment and Development (also known as the Earth Summit) in Rio de Janeiro, Brazil (UN-OHRLLS 2011). Small Island Developing States are located in three geographical areas. The highest number (29 SIDS) is in the Caribbean, followed by the Pacific Ocean area (20 SIDS) and the smallest number (9 SIDS) is found in the Atlantic Ocean, Indian Ocean, Mediterranean and South China Sea (i.e. AIMS). Despite the certain heterogeneity of the group, SIDS members share three key characteristics that make them unique in terms of development (UNWTO 2017). The first characteristic is their small size, resulting in an increased pressure on natural resources and limited diversity of the national economy. The second challenge is remoteness and isolation, which limit the development of trade while helping to preserve unique natural and cultural diversity. The third characterristic is the oceanic environment, which represents an opportunity in terms of tourism but at the same time makes them vulnerable to extreme climatic events and climate change. Although Small Island Developing States are more diverse in terms of economic and social development, a considerable number of them is characterized by a high degree of dependence on tourism in terms of its contribution to GDP and contribution to employment. 
The aim of the study is to uncover factors that may influence the number of international tourist visits to Small Island Developing States (SIDS). For this purpose, a panel regression analysis over 2005 - 2016 was employed. This methodological approach can be found in the literature on tourism development (Tasci 2007, Cho 2010 and Valek et al. 2014), however not in the context of SIDS. The dependent variable in the analysis is the annual number of tourist arrivals to individual SIDS. The following three groups of factors are used on the side of independent variables: geographical and environmental, economic, social and institutional.

The results indicate that the key determinants of tourism demand are destination accessibility, climate (pattern of the weather) and the level of economic development of destinations. The hygienic conditions and the level of tourism infrastructure development in SIDS are also important for tourism inflows. On the contrary, the level of political stability and absence of violence/terrorism plays a less statistically significant role in international tourists arrivals while the level of prices and the rate of intentional homicide do not show any statistical significance.

The results suggest that Small Island Developing States can encourage the development of their tourism industries by improving the transport infrastructure to enhance the accessibility of those destinations. They should also invest into the tourism infrastructure development as well as increase the hygienic standards to attract more international tourists. However, due to the inherent environmental fragility and cultural uniqueness of many small islands, the SIDS must pay special attention to sustainable tourism development. 
